\title{
Annals of Glaciology
}

Papers from the Seventh International Symposium on Antarctic Glaciology (ISAG-7), held in Milan, Italy, 25-29 August 2003 


\section{VOLUME 39}

\section{EDITORS}

Chief Editor

Associate Editors
Jo Jacka

$\begin{array}{ll}\text { Gino Casassa } & \text { Vicky Lytle } \\ \text { Massimo Frezzotti } & \text { Valter Maggi } \\ \text { Helen Fricker } & \text { Robert Mulvaney } \\ \text { Yoshiyuki Fujii } & \text { Tas van Ommen } \\ \text { Per Holmlund } & \text { Giuseppe Orombelli }\end{array}$

Wei Li Wang

\section{INTERNATIONAL GLACIOLOGICAL SOCIETY}

\begin{tabular}{|c|c|}
\hline President & Elizabeth Morris \\
\hline \multirow[t]{3}{*}{ Vice-Presidents } & Richard Alley \\
\hline & Eric Brun \\
\hline & Atsumu Ohmur \\
\hline Treasurer & John Heap \\
\hline Secretary General & Magnús Már M \\
\hline \multicolumn{2}{|c|}{ IN-HOUSE PRODUCTION } \\
\hline Production Manager & Christine Butler \\
\hline Production Assistant & Craig Baxter \\
\hline House Editor & Ken Moxham \\
\hline Publishing Assistant & Ann Leeding \\
\hline Typsetter/Programmer & Ali Woollatt \\
\hline
\end{tabular}

Cover illustration upper: Dome C summer camp, the new Concordia Station and the EPICA drilling facilities; lower: the ITASE traverse on the plateau (Antarctica)(photo from Massimo Frezzotti). 


\section{Annals of Glaciology}

Papers from the Seventh International Symposium on Antarctic Glaciology (ISAG-7), held in Milan, Italy, 25-29 August 2003 
The Annals of Glaciology contains peer-reviewed, edited papers from IGS-sponsored symposia. Papers in this publication are indexed in the Science Citation Index ${ }^{\circledR}$ Science Citation Index-Expanded (also known as Sci-Search ${ }^{\circledR}$ ), and ISI ${ }^{\circledR}$ Alerting services.

The accurary of references in the text and lists is the responsibility of the authors, to whom queries should be addressed.

The Annals of Glaciology is available online. Subscribers wishing to access the online papers should go to www.ingentaselect.com/register.htm and follow the online instructions. For subscription information contact igsoc@igsoc.com.

ISSN 0260-3055

ISSN 1727-5644 (Online)

ISBN 0-946417 342

(C) International Glaciological Society 2004

All rights reserved; no part of this publication may be reproduced, stored or retrieved in any form or by any means, electronic, mechanical, photocopying, recording, or otherwise without the prior written permission of the International Glaciological Society (IGS), except as stated below.

The Annals of Glaciology is registered with the Publishers Licensing Society Limited. Consent is given for single copies of single articles to be made for private study or research, or for the personal or internal use of specific clients, provided the appropriate fee is paid to The Copyright Licensing Agency, 90 Tottenham Court Road, London, W1P OLP (Fax: 020-7631-5555; e-mail: info@cla.co.uk). Illustrations and short extracts from the text of individual contributions may be made provided the source is acknowledged and permission is granted by the authors and the IGS. The IGS hereby gives permission for abstracts of articles in this issue to be reprinted by abstracting journals. 


\section{PREFACE}

This volume of Annals of Glaciology contains 87 papers presented to the Seventh International Symposium on Antarctic Glaciology (ISAG-7). Previous symposia in this series have been held at Helsinki, Finland (IAHS Pub. 55, 1961); Hanover, New Hampshire, USA (IAHS Pub. 86, 1970); Columbus, Ohio, USA (Ann. Glaciol. 3); Bremerhaven, Germany (Ann. Glaciol. 11); Cambridge, UK (Ann. Glaciol. 20); and Lanzhou, China (Ann. Glaciol. 29). The sponsor of these symposia has been the Scientific Committee on Antarctic Research (SCAR).

ISAG-7 was held at the University of Milano Bicocca, Milan, Italy on 25-29 August, 2003. Co-sponsors with SCAR, were the International Glaciological Society (IGS), the Italian Antarctic Research Programme (PNRA), the Italian Glaciological Committee (CGI), University of Milano-Bicocca (UNIMIB), Department of Environmental Sciences (DISAT), and the Italian Agency for New Technology, Energy and the Environment (ENEA). The local organising committee for the symposium was Giuseppe Orombelli (Chairman), Massimo Frezzotti and Valter Maggi. Financial support for publication of this volume was provided by the Italian Scientific Commission on Antarctic Research and by the Agency for the Environmental Protection of Lombardy.

There were 207 participants at the symposium, from 22 countries. Two hundred and eleven papers were presented, 109 as oral presentations and 102 as poster presentations. The 87 papers presented in this volume have all been refereed and edited in accordance with IGS's usual practices by an editorial committee consisting of Jo Jacka (Chief Editor), Gino Casassa, Massimo Frezzotti, Helen Amanda Fricker, Yoshiyuki Fujii, Per Holmlund, Vicky Lytle, Valter Maggi, Robert Mulvaney, Giuseppe Orombelli, Tas van Ommen and Wei Li Wang.

Along with ISAG-7, smaller workshops were conducted concerning the SCAR Standing Scientific Group on Physical Sciences Expert Groups on the International Trans Antarctic Scientific Expedition (ITASE), and Ice Sheet Mass Balance and Sea Level (ISMASS). There was also a meeting of a group of specialists on ice core collections for glaciological, cryobiological and climatological research (InterlCE). There was a call from the symposium organisers for submitted papers to present results from SCAR programmes. As a result several of the papers in this volume do contribute to ITASE, ISMASS, READER (REference Antarctic Data for Environmental Research) and SALE (Subglacial Antarctic Lake Exploration). Further results from programmes contributing to ITASE and ISMASS have been presented to a SCAR symposium in July 2004, and will be published in Ann. Glaciol. 41.

Jo Jacka 